\title{
Pigeonpea (Cajanus cajan) urease immobilized on alginate beads, showing improved stability and operational parameters
}

\author{
Sarmesh Arya ${ }^{1}$, Sandeep Kumar ${ }^{* 1}$, Pankaj Kumar ${ }^{1}$, Jitendra Singh ${ }^{2}$ and Anil Sirohi ${ }^{3}$ \\ ${ }^{1}$ Department of Biochemistry \& Physiology, ${ }^{2}$ Department of Immunology and Defense Mechanism, \\ ${ }^{3}$ Department of Molecular Biology and Genetic Engineering; College of Biotechnology; Sardar \\ Vallabhbhai Patel University of Agriculture \& Technology, Meerut 250110, India \\ *E-mail: sandeep4554@gmail.com
}

\begin{abstract}
Urease (urea amidohydrolase; EC 3.5.1.5) from pigeonpea (Cajanuscajan) was immobilized in alginate beads by entrapment method. Approximately $48 \%$ immobilization of urease in alginate was observed at $3.5 \%(\mathrm{w} / \mathrm{v})$ alginate with $0.65 \mathrm{mg}$ protein $/ 5 \mathrm{ml}$ alginate gel. The optimum temperature was $65{ }^{\circ} \mathrm{C}$ and $80{ }^{\circ} \mathrm{C}$ for soluble urease and immobilized urease, respectively whereas, the optimum $\mathrm{pH}$ was 7.3 for soluble and 8.0 for immobilized urease. It was observed that there was an increase in $\mathrm{K}_{\mathrm{m}}$ for immobilized urease (4.34 $\mathrm{mM})$ as compared to soluble urease $(3.30 \mathrm{mM})$. The immobilized urease showed a decrease in $\mathrm{V}_{\max }(0.769$ $\mu \mathrm{mol} \mathrm{NH} \mathrm{min}^{-1} \mathrm{mg}^{-1}$ protein) as compare to soluble enzymes $\left(0.80 \mu \mathrm{mol} \mathrm{NH} \mathrm{min}^{-1} \mathrm{mg}^{-1}\right.$ protein).The immobilized urease showed improved stability at $75^{\circ} \mathrm{C}$ and the $t_{1 / 2}$ of decay of urease activity was 12 min and $50 \mathrm{~min}$ for soluble and immobilized urease, respectively. Further, the immobilized urease retained more than $50 \%$ of the original activity after eight uses. Furthermore, the storage stability studiesdemonstrated $80 \%$ loss inenzyme activity of soluble urease after 50 days of storage at $4{ }^{\circ} \mathrm{Cwhereas}$ with immobilized urease, the loss was $51 \%$ under similar conditions. The $t_{1 / 2}$ was 30 days and 51 days for soluble and immobilized urease, respectively.
\end{abstract}

Key words: Immobilization, Pigeonpea, Cajanuscajan, Urease, Alginate

Paper cited: Arya, S., Kumar, S., Kumar, P., Singh, J. and Sirohi, A. (2018). Pigeonpea (Cajanuscajan) urease immobilized on alginate beads, showing improved stability and operational parameters. South Asian Journal of Food Technology and Environment, 4(1): 631-642.

\section{Introduction}

Urease (urea amidohydrolase; E.C. 3.5.1.5) is a highly specific enzyme and catalyzes the hydrolysis of urea to ammonia and carbon dioxide. This enzyme plays diverse roles and mainly involved in the nitrogen metabolism. The bacterial urease has been extensively studied may be due to simplicity of system and its significance in various pathological conditions and role in agriculture etc. All plants and bacterial urease are probably nickel metalloenzymes. Seed urease from jack bean (Canavalisensiformis) was the first example of a natural nickel metalloenzyme. It also occurs in many bacteria, fungi and several species of yeast. Recovery of enzymes from reaction solutions and separation of the enzymes from substrates and products are in general very difficult. These problems can be successfully tackled by immobilization of the enzyme. To date, several immobilized enzyme-based processes have proved economic and have been implemented on a larger scale, mainly in the food industry, where they replace free enzymecatalyzed processes, and in the manufacture of fine specialty chemicals and pharmaceuticals, particularly where asymmetric synthesis or resolution of enantiomers to produce optically pure products are involved (Wiseman 1993; 
Bullock 1995; van de Velde et al., 2002). The scale of the processes ranges from about $10^{6}$ tons per year for high-fructose corn syrup, arguably one of the most commercially important immobilized enzyme based processes, to about $10^{2}$ tons per year for enantiopure LDOPA (van de Velde et al., 2002). Immobilization of urease has been carried out in diverse matrices and immobilized urease has analytical and clinical applications (Das et al., 1997; Das et al., 1998; Das and Kayastha, 1998; Kayastha and Srivastava, 2001; Kayastha et al., 2003; Reddy et al., 2004) and possible future potential for the treatment of urea-containing effluents (Kamath et al., 1988; Kamath and D’Souza, 1991).

Calcium alginate is just as widely used as polyacrylamide. Unlike polyacrylamide gels, gelation of calcium alginate does not depend on the formation of more permanent covalent bonds between polymer chains. Rather, polymer molecules are cross-linked by calcium ions. Because of this, calcium alginate beads can be formed in extremely mild condition, which ensure that enzyme activity yields of over $70 \%$ can be routinely achieved. By mimicking the natural mode of occurrence in living cells, where enzymes for the most cases are attached to cellular membranes, the systems stabilize the structure of enzymes, hence their activities. Thus, as compared to free enzymes in solution immobilized enzymes are more robust and more resistant to environmental changes. More importantly, the heterogeneity of the immobilized enzyme systems allows easy recovery of enzymes and products, multiple reuses of enzymes, continuous operation of enzymatic processes, rapid termination of reactions and greater variety of bioreactor designs. The aim of this study was to immobilize pigeon pea urease on alginate beads and to investigate some factors in comparison with the free enzyme which may be used to gain knowledge on the effects of immobilization on enzyme properties.

\section{Materials and methods}

\section{Chemicals \& Enzyme}

Sodium alginate, Urea (Enzyme grade), Tris buffer, Bovine Serum Albumin (BSA), Calcium Chloride $\left(\mathrm{CaCl}_{2}\right)$, Nessler's Reagent (NR) and Trichloroacetic Acid (TCA) were purchased from Merck and Sisco Laboratories, India. All other reagents were of analytical grade either from Himedia or SRL. All reagents were prepared in DDW (double distilled water). Urease was isolated from mature seeds of pigeonpea.

\section{Urease Activity Assay}

Urease was assayed by determining the amount of ammonia liberated in a fixed time interval on incubating the enzyme and urea. A blank without enzyme was run side by side and correction was applied for the same. The Nessler's reagent was calibrated with standard ammonium chloride solution. An enzyme unit has been defined as the amount of urease required to liberate $1 \mu \mathrm{mol}$ of ammonia per min under our test conditions $(0.1 \mathrm{M}$ urea, $0.05 \mathrm{M}$ Tris-acetate buffer, $\left.\mathrm{pH} 7.0,37^{\circ} \mathrm{C}\right)$.

\section{Protein Estimation}

Protein content of urease preparation was estimated by the method of Lowery et al. (1951) using bovine serum albumin as standard.

\section{Immobilization of urease on alginate beads}

The stock solution of sodium alginate $5 \%(\mathrm{w} / \mathrm{v})$ was prepared in $25 \mathrm{mMTris}$ acetate buffer $\mathrm{pH} 7.3$ at $70^{\circ} \mathrm{C}$ with continuous stirring. Sodium alginate solution is best prepared by adding the powder to agitated water, rather than vice versa to avoid the formation of clumps. 
Pigeonpea (Cajanus cajan) urease immobilized on alginate beads, showing improved stability and operational parameters

Prolonged stirring may be necessary to achieve the complete dissolution of sodium alginate. After sodium alginate was completely dissolved; the solution was kept undisturbed for $30 \mathrm{~min}$ to eliminate the air bubbles that could later be entrapped and cause the beads to float. It was kept in a refrigerator for about 3 hours at $4^{\circ} \mathrm{C}$ and then mixed with suitably diluted urease preparation (fixed protein concentration). The concentration of alginate was varied over the range, ( 1 to $5 \% \mathrm{w} / \mathrm{v})$ while keeping the concentration of urease constant. A syringe was clamped at a height of $15 \mathrm{~cm}$ above $8 \% \mathrm{CaCl}_{2}$ (w/v) solution (stirred continuously) at $4^{\circ} \mathrm{C}$ and its nozzle was closed with a piece of parafilm. The solution was added drop wise extruding through a hole (dia. $1 \mathrm{~mm}$ ) in the parafilm. The alginate beads (dia. $2.6 \mathrm{~mm}$ ) of uniform size and shape were formed and left for stirring for another 2-3 hours to allow them to attain rigidity. Similarly the concentration of soluble urease was varied while keeping the alginate concentration constant and beads were made. Finally, the beads were washed with 25 mMTris acetate buffer, $\mathrm{pH} 7.3$ to remove the traces of $\mathrm{CaCl}_{2}$ and stored in same buffer at $4^{\circ} \mathrm{C}$.

\section{Activity assay of immobilized urease}

The immobilized urease was assayed by determining the amount of $\mathrm{NH}_{3}$ liberated in a fixed time intervals on incubating the urease beads in urea solution. Assay buffer $(0.05 \mathrm{M}$

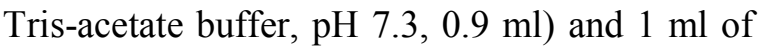
$0.2 \mathrm{M}$ urea solution were pre-incubated at $37^{\circ} \mathrm{C}$. Reaction was started by adding varying number of beads. After incubation for the required time (10 $\mathrm{min}$ ) the beads were removed from the reaction mixture to stop the reaction. $1 \mathrm{ml}$ of reaction mixture was transferred to a $50 \mathrm{ml}$ volumetric flask. Nessler's reagent $1.0 \mathrm{ml}$ was added to the test solution in the volumetric flask. The volume was made up to $50 \mathrm{ml}$ with DDW. Absorbance was measured at $405 \mathrm{~nm}$ (path length: $1 \mathrm{~cm}$ ) on spectrophotometer. A blank without enzyme was run side by side and correction was applied for the same.

\section{Steady state kinetics}

Effect of pH: The optimum $\mathrm{pH}$ of soluble and immobilized urease was determined by preparing assay buffer of varying $\mathrm{pH}$ values (4-10). The activity assay was performed at the different $\mathrm{pH}$ and percent relative activity of soluble and immobilized enzymes was determined.

Effect of temperature: The effect of temperature was investigated by varying the temperature from $10^{\circ} \mathrm{C}$ to $90^{\circ} \mathrm{C}$. All forms of urease were incubated at the indicated temperature and were added to pre-incubated urea solution (at respective temperature) to measure the enzyme activity as stated earlier. The percent relative activity of soluble and immobilized enzyme was determined.

\section{Effect of substrate concentration:}

Effect of substrate concentration on urease activity was investigated at $37^{\circ} \mathrm{C}$ by varying the urea concentration. $1 \mathrm{M}$ stock solution of substrate (urea) was prepared in assay buffer and different concentrations (1 to $12 \mathrm{mM}$ Urea) of same were made. The activity assay was performed and the values of $\mathrm{K}_{\mathrm{m}}$ and $\mathrm{V}_{\max }$ were determined by Lineweaver-Burk plot.

\section{Stability studies}

Reusability: The immobilized urease was tested for its reusability by checking the activity at different intervals. After every use beads were washed properly with 25 mMTrisacetate buffer, $\mathrm{pH} 7.3$ and stored in the same buffer at $4^{\circ} \mathrm{C}$ till further use.

Thermal inactivation: The soluble and immobilized urease was incubated at $75^{\circ} \mathrm{C}$ in a water bath for a time interval. The enzyme 
(soluble and immobilized) was taken out at the specified intervals, chilled immediately and transferred to assay mixture. The activity assay was performed and residual activity was determined. The $t_{1 / 2}$ values for soluble and immobilized urease were determined from the semi log plot.

Storage stability: The soluble and immobilized urease was stored in 25 mMTrisacetate buffer, $\mathrm{pH} 7.3$ at $4^{\circ} \mathrm{C}$ and enzyme activity was determined at different days as indicated. The $t_{1 / 2}$ of soluble and immobilized urease was calculated from the plot.

\section{Results and discussion}

\section{Immobilization of urease on alginate beads}

Enzymes can be immobilized to a multitude of different carriers by entrapment, adsorption, ionic binding and covalent binding. Covalent binding is very effective in retaining the enzyme and can achieve high activity after immobilization. The entrapment and adsorption methods are less efficient as compared to covalent methods, but these methods are comparatively easier to perform, and are less harsh to enzyme besides, being inexpensive. These methods find applications in medicines, agriculture and analytical tools, where they can replace chemicals, which might be toxic and harsh to living systems.

The structural integrity and activity of the urease were retained due to mild and precise physical condition during the immobilization procedure. The alginate beads were chemically inert to the entrapped enzyme. The porosity of the gel was such that it allowed easy movement of the substrate molecules through the beads. The beads were quite stable in Tris buffer $(\mathrm{pH}$ 7.3). However at higher $\mathrm{pH}$ values, the beads showed softening and stickiness of the surface. Alginate beads are hydrophilic in nature. During preparation of alginate beads, the beads were soft and flaccid at lower concentrations of the alginate, while there was low percent immobilization at higher concentrations (Table 1). The diffusional resistances offered by alginate gel at higher concentration to substrate might be responsible for decreased hydrolysis of urea and therefore percent immobilization was affected. It was observed that with $3.5 \%$ alginate $(\mathrm{w} / \mathrm{v})$, rounded and uniformly shaped beads (dia. $2.6 \mathrm{~mm}$ ) were formed and yielded $32 \%$ immobilization. Therefore, the concentration of sodium alginate was fixed at $3.5 \%$ for subsequent experiments. Protein concentration was varied and the best immobilization observed was $48 \%$ at $0.65 \mathrm{mg}$ protein $/ 5 \mathrm{ml}$ alginate gel. At higher protein concentrations, the immobilization efficiency was reduced. While standardizing conditions for urease immobilization on the alginate, the volume of enzyme solution $(0.9 \mathrm{ml})$ and number of beads incubated (four) were kept constant in all the experiments.

Some plant sources have been immobilized successfully on different matrices with varying efficiencies, viz. on gelatin via glutaraldehyde, 67.6\% (Kumar et al., 2005); on agar by entrapment, 51.7\% (Swati et al., 2007); on gelatin via glutaraldehyde, $75 \%$ (Srivastava and Kayastha, 2001); on polyacrylamide, 50\% (Das et al., 1998); on DEAE-cellulose paper, $51 \%$ (Reddy et al., 2004); flannel cloth via polyethyleneimine, 56\% (Das and Kayastha, 1998). In addition, there are many reports of urease immobilization on various hydrogels by means of different methods, e.g., on poly (acrylonitrile) chitosan composite membranes; on chitosan-alginate polyelectrolyte complexes (C-A PEC) and poly(acrylamide-co-acrylic acid)/kappa-carrageenan [P(AAm-coAA)/carrageenan] hydrogels (Kara et al., 2006); encapsulation within kappa-carrageenan beads (Baysal and Karagoz, 2005); within 
polyanioniccarboxy methyl cellulose/alginate (CMC/Alg) microspheres coated with a cationic polysaccharide, chitosan (C) (Elcin and Elcin, 2000).

\section{Steady-state kinetics}

The effect of $\mathrm{pH}$ on the activity of free and immobilized urease is shown in Fig.1. The optimum $\mathrm{pH}$ of soluble and immobilized urease was 7.3 and 8.0, respectively. There was a shift of 0.7 units of $\mathrm{pH}$ towards the basic side, which might have been due to entrapment of urease. However, Jack bean urease immobilized on porous glass beads have showed the $\mathrm{pH}$ optimum of 7.2 for the soluble and 6.1 for immobilized enzyme (Lyengar et al., 1982). In case of alkylamine immobilization of pigeonpea urease, a shift was observed from 7.3 (soluble) to 6.5 (immobilized) (Reddy and Kayastha, 2006). However, immobilized enzyme maintained a higher relative activity than free urease at both lower and higher $\mathrm{pH}$ levels, indicating that the immobilized enzyme was less sensitive to $\mathrm{pH}$ changes than the free urease. The behavior of an enzyme molecule may be modified by its immediate micro-environment. An enzyme can have an altered $\mathrm{pH}$ optimum upon immobilization on a solid matrix in relation to its $\mathrm{pH}$ optimum in solution. Depending on the surface and residual changes on the solid matrix and the nature of the enzyme bound, the $\mathrm{pH}$ value in the immediate vicinity of the enzyme molecule may change thus causing a shift in the $\mathrm{pH}$ optimum of the enzyme (Mosbach, 1971; Kayastha and Srivastava, 2001; Reddy and Kayastha, 2006).

The effect of temperature on soluble and immobilized urease was studied at different temperatures (Fig. 2). The optimum temperature for soluble urease was found to be $65^{\circ} \mathrm{C}$. The optimum temperature for immobilized urease was found to be $80^{\circ} \mathrm{C}$. The increase in the value of optimum temperature of immobilized enzyme could be due to the fact that the actual temperature in the micro-environment of the gel matrix was lower than in the bulk solution (Prakash et al., 2007). The similar increased optimum temperature of immobilized urease was also observed by others. Clearly at high temperatures, loss in the urease activity of soluble form was due to denaturation of enzyme. The improved stability of immobilized enzyme was supposed to be aided by the matrix, which absorbs a considerable amount of heat and protects the enzyme against denaturation. In industries, most of the operations are carried out either at room or higher temperatures. Usually, the immobilization improves enzyme stability against the higher temperatures and therefore makes the enzyme industrially more useful and economical.

The pigeonpea urease was immobilized in alginate gel by entrapment method and investigated for the effect of substrate concentration on urease activity. The diffusion of urea through the alginate matrix appears to exert the major influence on the observed kinetics. The matrix often prevents free diffusion of substrate and therefore results in changed $\mathrm{K}_{\mathrm{m}}$. It was observed that there was a significant increase in $\mathrm{K}_{\mathrm{m}}$ of immobilized urease $(4.34 \mathrm{mM})$ as compared to the soluble urease $(2.22 \mathrm{mM})$, which may be due to the diffusional resistance offered by the gel (Fig. 3). The urea takes more time to reach the site of catalysis and therefore it results in the increase in $\mathrm{K}_{\mathrm{m}}$. It is postulated that an unstirred layer of solvent surrounds suspended water-insoluble particles. This unstirred layer is known as the "Nernst layer" and with water insoluble enzymes (i.e., immobilized enzymes), a concentration gradient of substrate is established across the layer. Consequently, saturation of an enzyme attached to a water-insoluble particle will occur at a higher substrate concentration than normally required for the saturation of the freely soluble 
enzyme, thus leading to an increase in the $\mathrm{K}_{\mathrm{m}}$ value. Similar changes in $\mathrm{K}_{\mathrm{m}}$ have also been reported for urease when immobilized by encapsulation and adsorption methods on various matrices such as chitosan, gelatin, DEAE-cellulose paper, etc. The alginate immobilized ureases showed a decrease in $\mathrm{V}_{\max }$ (0.769 $\mu \mathrm{mol} \mathrm{NH} \mathrm{min}^{-1} \mathrm{mg}^{-1}$ protein) as compare to soluble enzymes $\left(0.80 \mu \mathrm{mol} \mathrm{NH} \mathrm{Nin}^{-1} \mathrm{mg}^{-1}\right.$ protein). From the earlier reports on soybean ureases, it have been shown that the $\mathrm{V}_{\max }$ values of alginate immobilized urease, chitosanimmobilized urease and soluble urease were $2.82 \times 10^{2} \mu \mathrm{mol} \mathrm{NH}_{3} \min ^{-1} \mathrm{mg}^{-1}$ protein, $2.65 \times 10^{2} \mu \mathrm{mol} \mathrm{NH} \mathrm{NHin}^{-1} \mathrm{mg}^{-1}$ protein and $2.85 \times 10^{2} \mu \mathrm{mol} \mathrm{NH}_{3} \mathrm{~min}^{-1} \mathrm{mg}^{-1}$ protein, respectively (Kumar et al., 2009).

\section{Stability studies}

For industrial use of enzymes, it is important to consider the enzyme stability with respect to various parameters like temperature, reusability, storage stability, etc. The soluble enzyme cannot be recovered from the reaction mixtures and therefore cannot be used to catalyze more reactions, but the process of immobilization can make it feasible. The operational stability of immobilized enzyme systems is one of the most important criteria for various biotechnological and biomedical applications; an increased stability could make the immobilized enzyme more advantageous than its free counterparts. The urease was investigated for the reusability studies. The studies revealed that the alginate immobilized urease after 8 uses retained more than $50 \%$ of the original activity (Fig.4).

Table 1: Standardization of various parameters for immobilization of urease in alginate beads

\begin{tabular}{|c|c|c|}
\hline $\begin{array}{c}\text { Concentration of sodium } \\
\text { alginate } \mathbf{\%}(\mathbf{w} / \mathbf{v})\end{array}$ & $\begin{array}{c}\text { Protein/5 } \mathbf{~ m l ~ o f ~} \\
\text { alginate gel }\end{array}$ & $\begin{array}{c}\text { Immobilization } \\
\mathbf{( \% )}\end{array}$ \\
\hline 1 & 0.952 & No beads \\
\hline 2 & 0.952 & 24 \\
\hline 3 & 0.952 & 30 \\
\hline 3.5 & 0.952 & 32 \\
\hline 4 & 0.952 & 29 \\
\hline 5 & 0.952 & 27 \\
\hline 3.5 & 0.392 & 34 \\
\hline 3.5 & 0.483 & 38 \\
\hline 3.5 & 0.65 & 48 \\
\hline 3.5 & 0.98 & 41 \\
\hline 3.5 & 1.1 & 35 \\
\hline
\end{tabular}




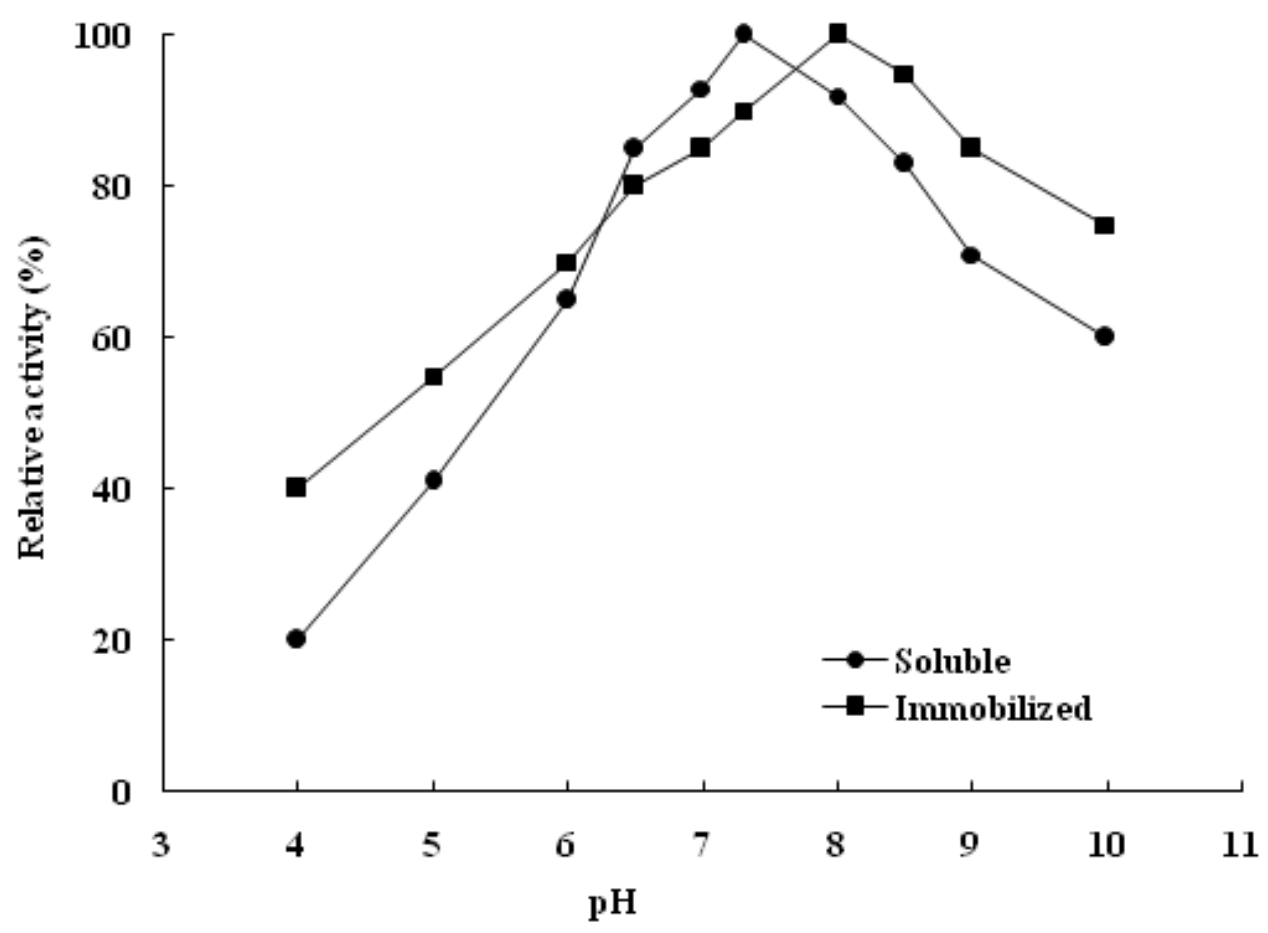

Fig. 1: Effect of $\mathrm{pH}$ on the activity of soluble and immobilized urease

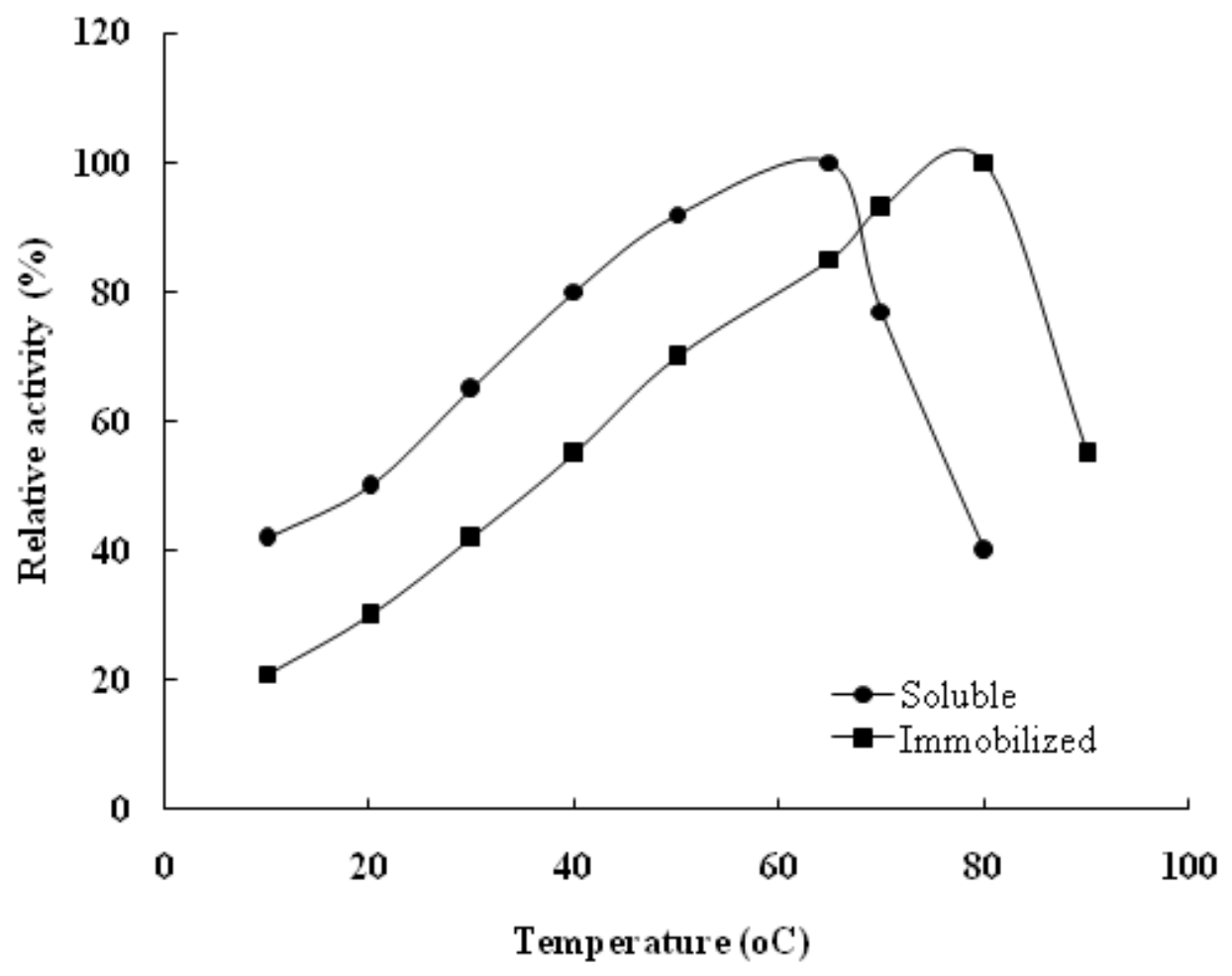

Fig. 2: Effect of temperature on the activity of soluble and immobilized urease. 
Sarmesh Arya, Sandeep Kumar, Pankaj Kumar, Jitendra Singh and Anil Sirohi

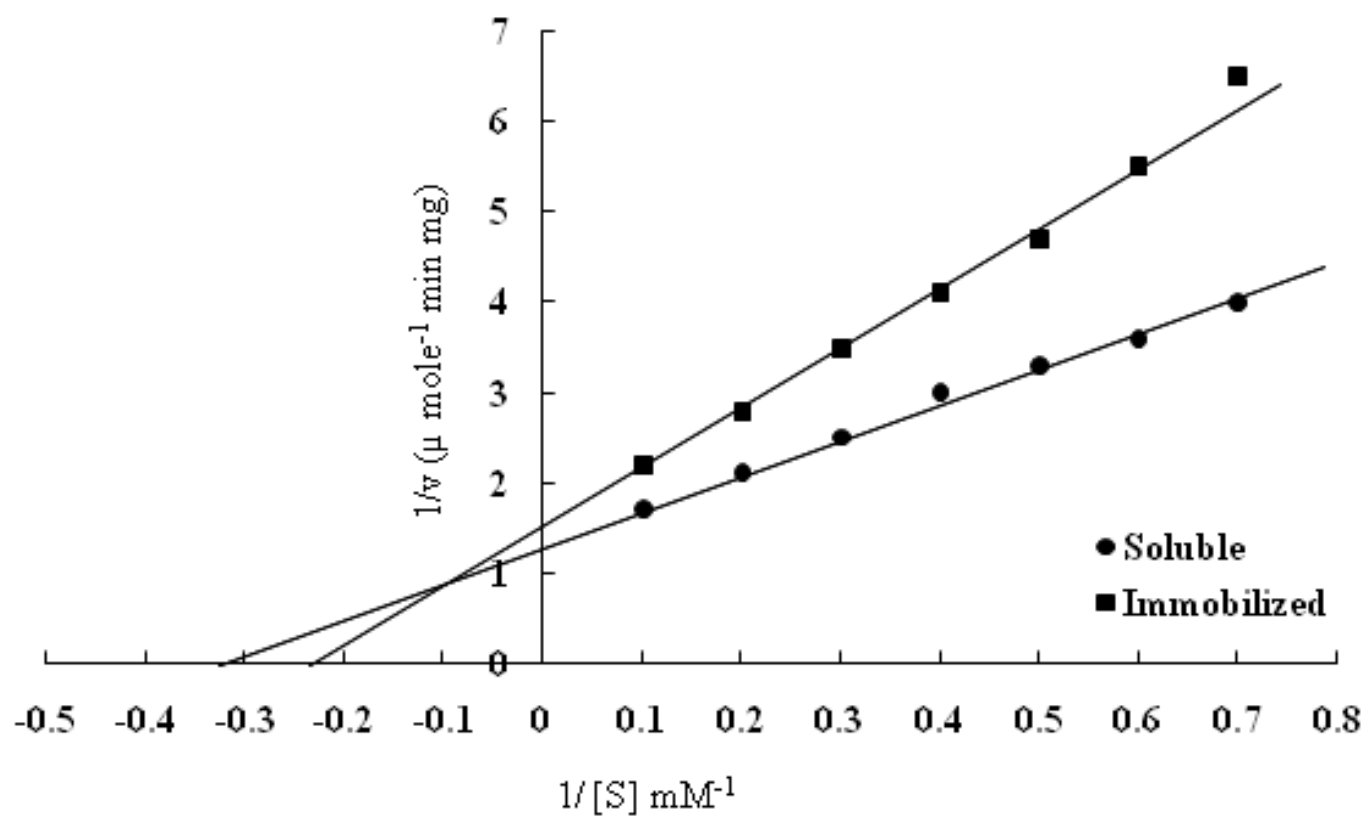

Fig. 3: Determination of $K m$ and $V_{\max }$ for soluble and immobilized urease by Linew eaver Burkplot.

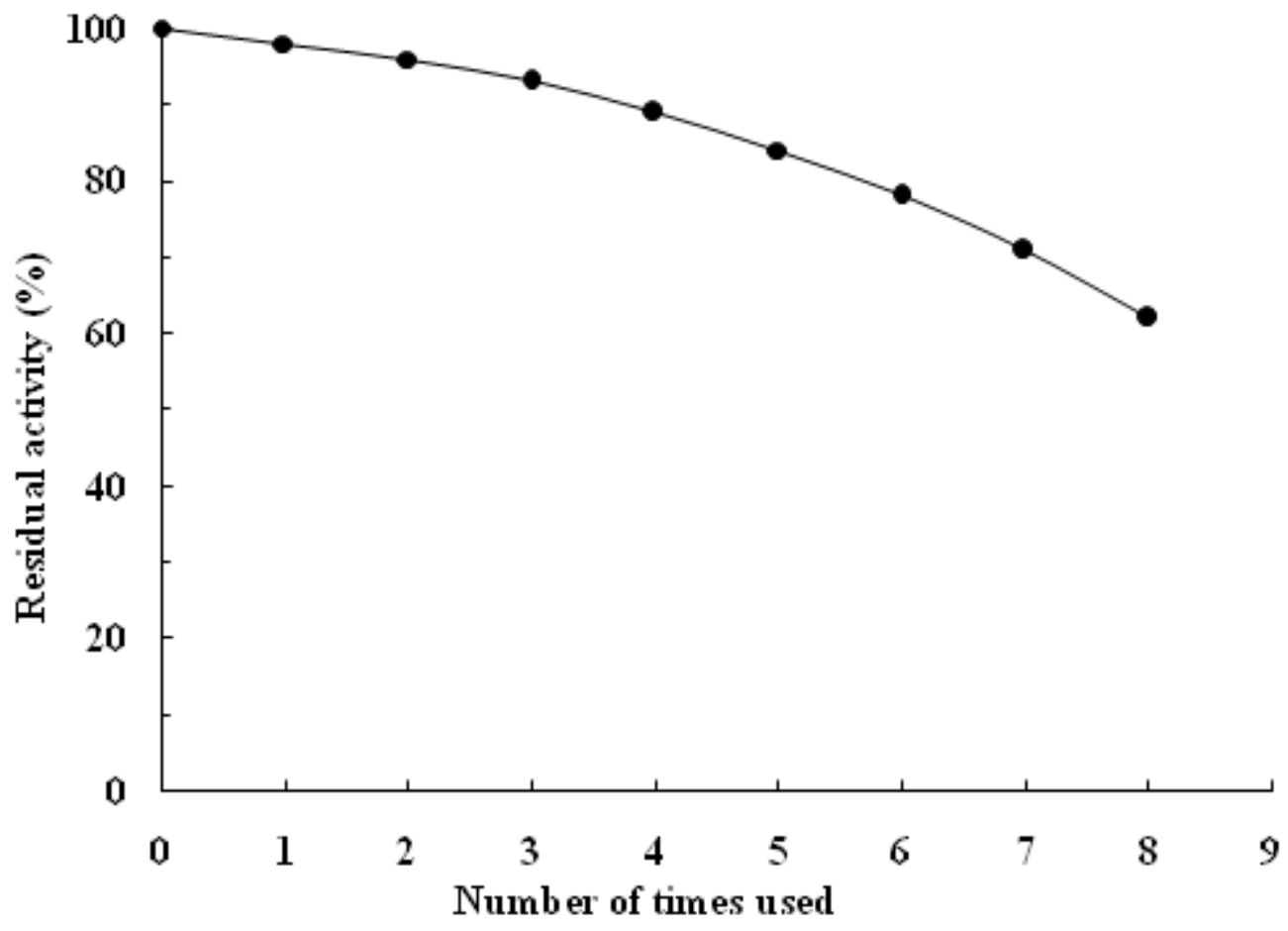

Fig. 4: Reusability studies of immobilized urease. 
Pigeonpea (Cajanus cajan) urease immobilized on alginate beads, showing improved stability and operational parameters

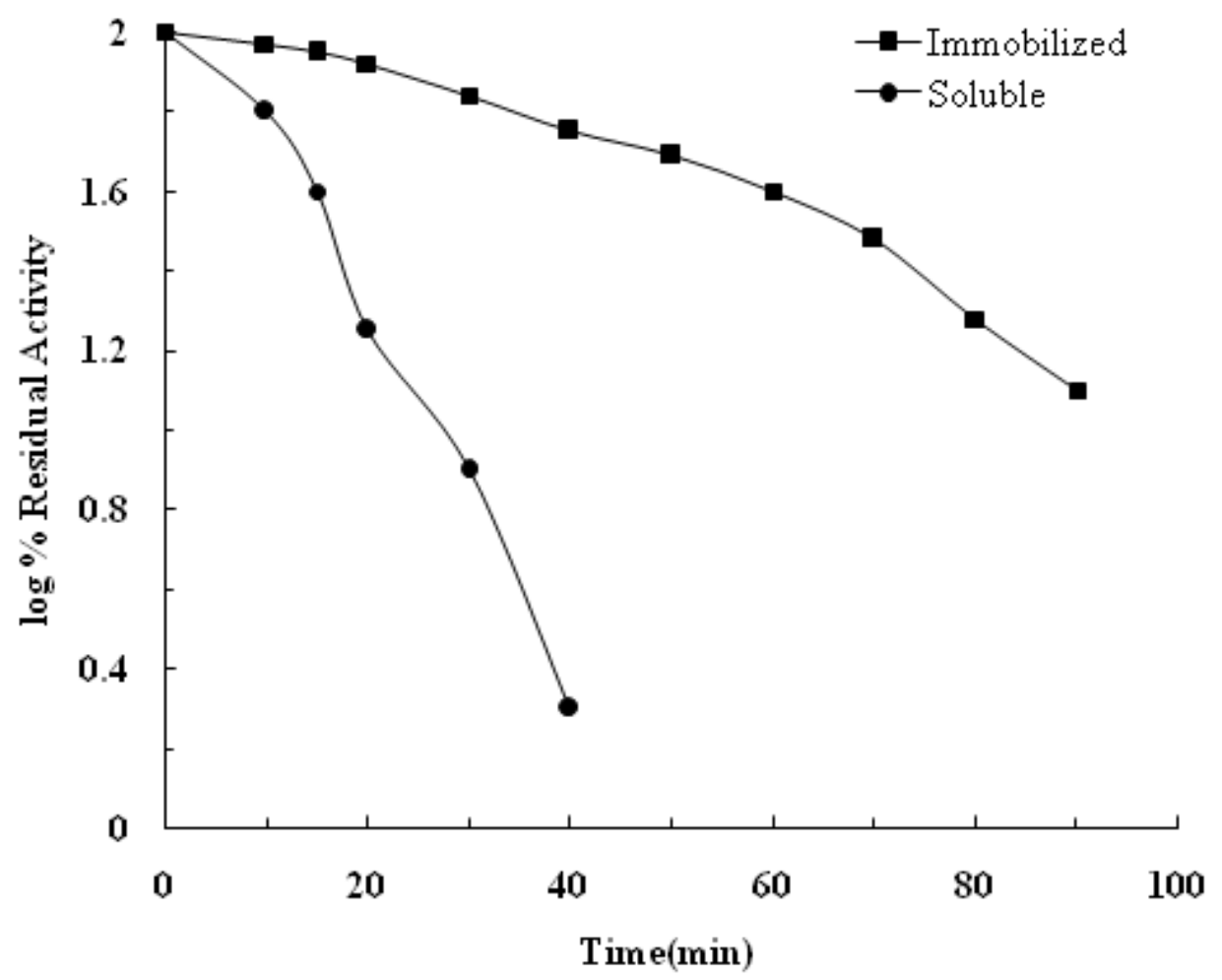

Fig. 5: Time-dep end ent thermal inactivation studies of soluble and immobilized urease.

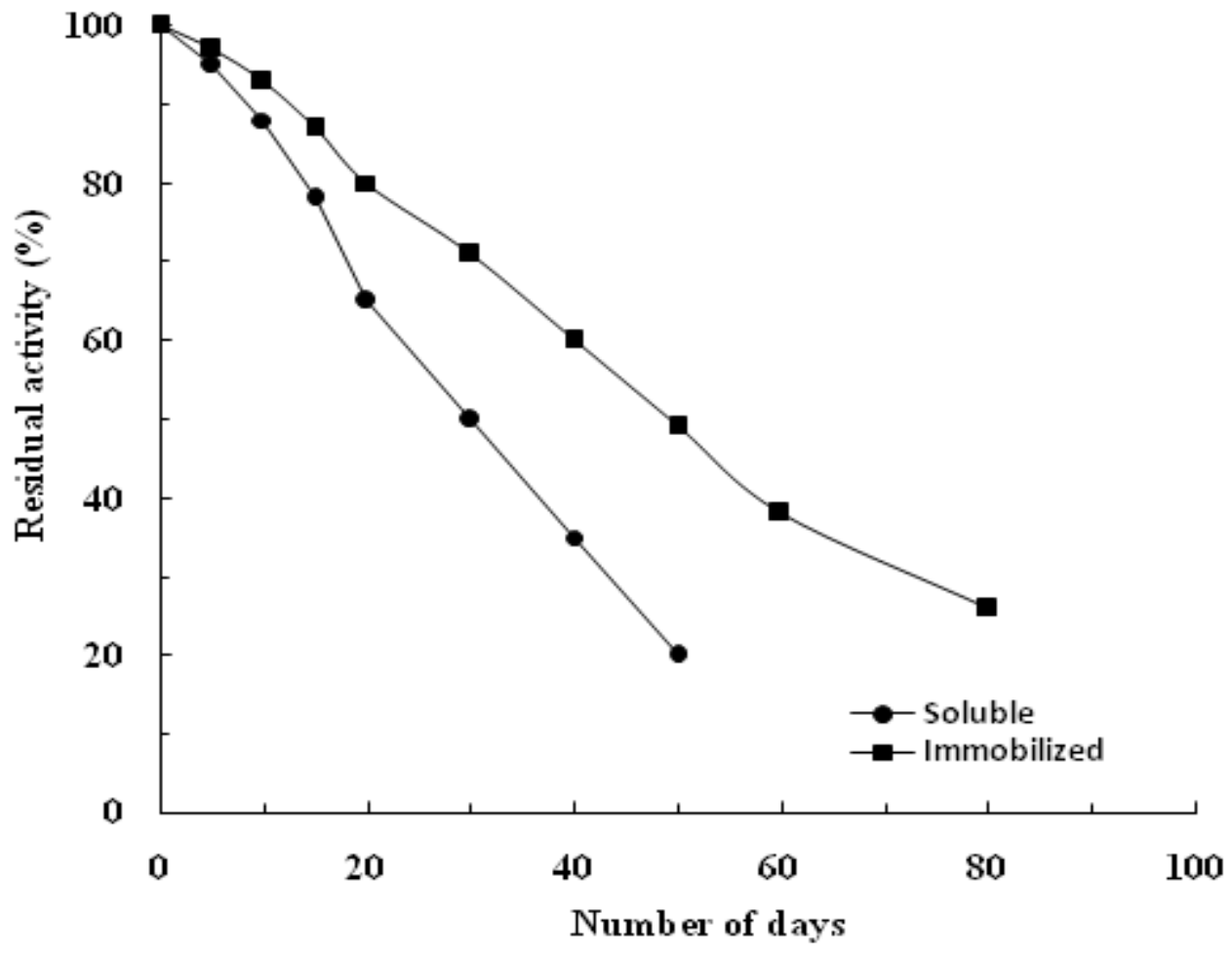

Fig. 6: Storage stability studies of soluble and immobilized urease. 
The soluble as well as the immobilized urease were incubated at $75^{\circ} \mathrm{C}$ for the indicated time intervals and the data collected were analyzed for thermal stability (Fig.5). When the $\log \%$ residual activity was plotted against time at $75^{\circ} \mathrm{C}$, the free enzyme showed first-order reaction, but the immobilized enzyme follows non-linear relation. Evidently, the rate of decay of enzyme activity at $75^{\circ} \mathrm{C}$ (elevated temperatures) with time was significantly reduced after immobilization. Although, the rate was not linear for immobilized urease, but was almost in single phase. It clearly establishes the improved stability of immobilized urease against elevated temperatures after incubation for longer durations. The $t_{1 / 2}$ value of decay was about 12 $\mathrm{min}$ and $50 \mathrm{~min}$ for free and immobilized enzyme, respectively. The conformational elasticity of the enzyme is affected by immobilization. It is often found that immobilized enzyme has a higher thermal stability than that of free enzyme because of restriction of conformational elasticity in immobilized enzyme.

The stability of an enzyme is of significant importance for scheduling its application in a particular reaction. The residual activity of the enzyme was determined as a function of time using urea as substrate and results are given in Fig.5. For storage stability studies, the immobilized urease was always kept in 50 mMTris-acetate buffers, $\mathrm{pH} 7.3$ at $4^{\circ} \mathrm{C}$. All forms of urease were assayed on different days over a period of 80 days. The plot of $\%$ residual activity versus the number of days gave a $t_{1 / 2}$ of 30 days for soluble urease and 51 days for alginate-immobilized urease.The loss of activity, for soluble urease after 50 days of storage at $4^{\circ} \mathrm{C}$ was $80 \%$ and in comparison to alginate immobilized urease the loss was 51\% (Fig.6). This clearly signifies that entrapment of enzyme into alginate beads had tremendously improved the storage stability of urease and this is one of the biggest advantages of urease immobilization on alginate beads. From earlier reports, storage stability $\left(t_{1 / 2}\right)$ of immobilized pigeonpea urease on agar, flannel cloth, chitosan and DEAEcellulose paper strip were 70, 75,110 and 150, respectively at $4{ }^{\circ} \mathrm{C}$ (Das and Kayastha, 1998; Das et al., 1998; Kayastha and Srivastava, 2001; Reddy et al., 2004).

\section{Conclusion}

Immobilization of urease is of importance due to multiple practical applications of the enzyme. Immobilized enzymes are used in food technology, biotechnology, biomedicine and analytical chemistry. They have various advantages over free enzymes including easy separation of the reactants, products and reaction media, easy recovery of the enzyme, and repeated or continuous reuse. In analytical applications immobilized enzymes are used chiefly in biosensors and to a lesser extent, in diagnostic test strips. The low cost of pigeonpea, its readily availability, and the ease of urease immobilization in alginate beads described in the present study, makes it a suitable product for future applications in therapeutic and diagnostic.

\section{Acknowledgements}

Facilities provided by Department of Biochemistry \& Physiology and Center of Excellence in Agri-Biotechnology, College of Biotechnology, Sardar Vallabhbhai Patel University of Agriculture \& Technology, Meerut, are gratefully acknowledged.

\section{References}

1. Baysal, S.H. and Karagoz, R. (2005). Preparation and characterization of kappacarrageenan immobilized urease. Preparative Biochemistry \& Biotechnology, 35: 135-143. 
2. Bullock, C. (1995). Immobilized enzymes. Science Progress, 78: 119-134.

3. Das, N., Prabhakar, P., Kayastha, A.M. and Srivastava, R.C. (1997). Enzyme entrapped inside the reverse micelle in the fabrication of new urea biosensor. Biotechnology and Bioengineering, 54: 619-623.

4. Das, N. and Kayastha, A.M. (1998). Immobilization of urease from pigeonpea (CajanuscajanL.) in flannel cloth using polyethyleneimine. World Journal of Microbiology and Biotechnology, 14: 927929.

5. Das, N., Kayastha, A.M. and Malhotra, O.P. (1998). Immobilization of urease from seeds of pigeonpea (CajanuscajanL.) in polyacrylamide gels and calcium alginate beads. Biotechnology and Applied Biochemistry, 27: 25-29.

6. Elcin, A.E. and Elcin, Y.M. (2000). Polycation-coated polyanion microsphere of urease for urea hydrolysis. Artificial cells Blood Substituting Immobilized Biotechnology, 28: 95-111.

7. Kamath, N. and D'Souza, S.F. (1991). Pigeonpea (Cajanuscajan L.) urease immobilized on glutaraldehydeactivated chitosan beads and its analytical applications. Enzyme and Microbial Technology, 13: 935-938.

8. Kamath, N., Melo, J.S. and D'Souza, S.F. (1988). Pigeonpea (Cajanuscajan L.) urease immobilized on glutaraldehyde-activated chitosan beads and its analytical applications. Applied Biochemistry and Biotechnology, 19: 251-258.

9. Kara, F., Demirel, G. and Tumturk, H. (2006). Immobilization of urease by using chitosan-alginate and poly(acrylamide-co-acrylic acid)/kappacarrageenan supports. Bioprocess and Biosystems Engineering, 29: 207-211.
10. Kayastha, A.M. and Srivastava, P.K. (2001). Pigeonpea (Cajanuscajan L.) urease immobilized on glutaraldehyde activated chitosan beads and its analytical applications. Applied Biochemistry and Biotechnology, 96: 41-53.

11. Kayastha, A.M., Srivastava, P.K., Miksa, B. and Slomkowski, S. (2003). Unique activity ureases immobilized on poly (styrene-co-acrolein) microspheres. Journal of Bioactive and Compatible Polymers, 18: 113-124.

12. Kumar, S., Dwevedi, A. and Kayastha, A.M. (2009). Immobilization of soybean (Glycine max) urease on alginate and chitosan beads showing improved stability: Analytical applications. Journal of Molecular Catalysis BEnzymatic, 58:138-14.

13. Kumar, S., Kansal, A. and Kayastha, A.M. (2005). Immobilization of jack bean (Canavaliaensiformis) urease on gelatin and its characterization. Oriental Pharmacy and Experimental Medicine, 5: 43-47.

14. Lyengar, L., Bajpai, P. and Prabhakara Rao, A.V. (1982). Behavior of Molecular sieve bound urease. Indian Journal of Biochemistry and Biophysics, 19: 130-134.

15. Mosbach, K. (1971). Matrix-bound enzymes. II. Studies on a matrix-bound two-enzyme-system. Acta Chemica Scandinavica, 24: 2093-2100.

16. Prakash, O., Puliga, S. and Lata Upadhyay, S.B. (2007). Immobilization of watermelon (Citrullus vulgaris) urease in agarose gel for urea estimation. Biotechnology and Bioprocess Engineering, 12: 131-135.

17. Reddy, K.R.C. and Kayastha, A.M. (2006). Boric acid and boronic acids inhibition of pigeonpea urease. Journal 
of Enzyme Inhibition and Medicinal Chemistry, 21: 467-470.

18. Reddy, K.R.C., Srivastava, P.K., Dey, P.M. and Kayastha, A.M. (2004). Immobilization of pigeonpea (Cajanuscajan) urease on DEAEcellulose paper strips for urea estimation. Biotechnology and Applied Biochemistry, 39: 323-327.

19. Srivastava, P.K. and Kayastha, A.M. (2001). Studies on the histidine residues in pigeonpea (Cajanuscajan L.) urease. Journal of Molecular Catalysis BEnzymatic, 16: 81-89.

20. Swati, M., Kumar, S., Reddy, K.R.C. and Kayastha, A.M. (2007). Immobilization of urease from pigeonpea (Cajanuscajan) on agar tablets and its application in urea assay. Applied Biochemistry and Biotechnology, 142: 291-297.

21. Van de Velde, F., Lourenço, N.D., Pinheiro, H.M. and Bakker, M. (2002). Carrageenan: a food-grade and biocompatible support for immobilization techniques. Advanced Synthesis and Catalysis, 344: 815-835.

22. Wiseman, A. (1993). Designer enzyme and cell applications in industry and in environmental monitoring. Journal of Chemical Technology and Biotechnology, 56: 313-350.

$\begin{array}{ll}\text { Received } & \text { : April, } 2018 \\ \text { Revised } & \text { : May, 2018 } \\ \text { Published } & \text { : June, 2018 }\end{array}$

